\title{
Ultra-low temperature district heating system with central heat pump and local boosters for low-heat-density area: Analyses on a real case in Denmark
}

\author{
Yang, Xiaochen; Svendsen, Svend
}

Published in:

Energy

Link to article, DOI:

10.1016/j.energy.2018.06.068

Publication date:

2018

Document Version

Peer reviewed version

Link back to DTU Orbit

Citation (APA):

Yang, X., \& Svendsen, S. (2018). Ultra-low temperature district heating system with central heat pump and local boosters for low-heat-density area: Analyses on a real case in Denmark. Energy, 159, 243-251.

https://doi.org/10.1016/j.energy.2018.06.068

\section{General rights}

Copyright and moral rights for the publications made accessible in the public portal are retained by the authors and/or other copyright owners and it is a condition of accessing publications that users recognise and abide by the legal requirements associated with these rights.

- Users may download and print one copy of any publication from the public portal for the purpose of private study or research.

- You may not further distribute the material or use it for any profit-making activity or commercial gain

- You may freely distribute the URL identifying the publication in the public portal 


\section{Accepted Manuscript}

Ultra-low temperature district heating system with central heat pump and local boosters for low-heat-density area: Analyses on a real case in Denmark

Xiaochen Yang, Svend Svendsen

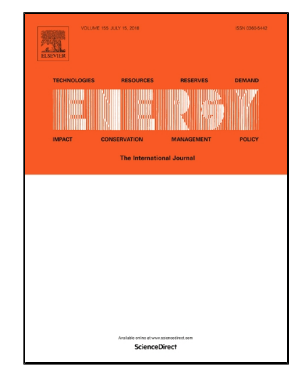

PII: $\quad$ S0360-5442(18)31133-2

DOI: $\quad 10.1016 / j$.energy.2018.06.068

Reference: $\quad$ EGY 13110

To appear in: $\quad$ Energy

Received Date: $\quad 03$ November 2017

Accepted Date: $\quad 10$ June 2018

Please cite this article as: Xiaochen Yang, Svend Svendsen, Ultra-low temperature district heating system with central heat pump and local boosters for low-heat-density area: Analyses on a real case in Denmark, Energy (2018), doi: 10.1016/j.energy.2018.06.068

This is a PDF file of an unedited manuscript that has been accepted for publication. As a service to our customers we are providing this early version of the manuscript. The manuscript will undergo copyediting, typesetting, and review of the resulting proof before it is published in its final form. Please note that during the production process errors may be discovered which could affect the content, and all legal disclaimers that apply to the journal pertain. 


\title{
Ultra-low temperature district heating system with central heat pump and local boosters for low-heat-density area: Analyses on a real case in Denmark
}

\author{
$\underline{\text { Xiaochen Yang }}{ }^{1 *}$. Svend Svendsen \\ ${ }^{1.2}$ Civil Engineering Department. \\ Technical University of Denmark. Denmark \\ Building 118. Brovej \\ DK-2800 Kgs. Lyngby. Denmark \\ Email:xiay@byg.dtu.dk ${ }^{1 *}$.Tel: +45 52908567
}

\begin{abstract}
Low temperature district heating $(\mathrm{DH})$ system gives easier access to the renewable energy as heat sources and improves the heat distribution efficiency. From the exergy point of view, low DH supply temperature also better matches the exergy demand of space heating and domestic hot water. It is more beneficial to operate district heating system under lower temperature level for the heat-sparse area where the distribution losses accounts for a large proportion in the total heat supply. In this study, the actual performance of a case ultra-low temperature district heating (ULTDH) system in Denmark was investigated based on long-term measurements. The system combines the central heat pump and local boosters, while the impact of such configuration on the overall system performance was analysed. The energy, exergy and economy performances of the case system were compared to medium temperature district heating system (MTDH) and low-temperature district heating system (LTDH). The results show that the LTDH system without supplementary heating has the highest energy and exergy efficiency. While the ULTDH system has better performance compared to the
\end{abstract}


MTDH system in energy, exergy and economy due to substantial savings from the distribution heat loss.

\section{Keywords}

Ultra-low temperature district heating, ground source heat pump, exergy, distribution heat loss, renewable heat source, local booster

\section{Highlights}

- A case ULTDH network for low-heat-density area was measured for long term.

- The ULTDH system was analysed from energy, exergy and economy aspects.

- The impact of using renewable energy source and local boosters was analysed.

- The performance was compared with MTDH system $\left(70 / 40{ }^{\circ} \mathrm{C}\right)$ and $\operatorname{LTDH}\left(55 / 25^{\circ} \mathrm{C}\right)$ system.

\section{Introduction}

To mitigate the huge unnecessary waste during the energy utilization process and the resulting environment problems, many governments have action plans to improve the efficiency of the energy systems. EU has a goal of reducing $32 \%-41 \%$ of primary energy consumption by the year 2050 compared to 2005-2006, as well as increasing the share of renewable energy sources (RES) in the final energy consumption to at least $55 \%$ by the year 2050 compared to the current situation (10\%)[1]. While according to the energy strategy in Denmark, the energy consumption for heat and electricity supply in the building sector was targeted to be completely fossil-free by the year 2035[2][3]. 
District heating $(\mathrm{DH})$ can aggregate different energy sources for heat supply. It is a cost efficient way of supplying heat to cities or regions with high heat density compared with individual heating methods. In Scandinavian countries, the heating area covered by district heating can reach $70 \%-90 \%$ of the total city areas [4]. Therefore, it is of great importance to make district heating systems more efficient and sustainable. One of the key indicator is the ability of utilizing renewable heat and recycled heat from low temperature sources[5]. Currently, most district heating systems are operated with medium-temperature, the heat carrier of which is normally the pressurized water under $100^{\circ} \mathrm{C}$ and produced by conventional heat sources (such as Large-scale CHP, distributed CHP, biomass and waste, or fossil fuel boilers) [5]. However, the high operation temperature of $\mathrm{DH}$ becomes a more and more serious issue that restricts the overall efficiency for heat delivery because of the distribution losses. For most existing DH network operated under medium temperature, the average distribution heat losses on a yearly basis is around $10-30 \%[6,7]$. The situation in the low-heat-density area is more severe. To reduce the temperature levels of district heating system not only allows a broader variety of renewable energy sources but also improves the system efficiency by decreasing the distribution losses.

According to the definitions of different generations of district heating $[5,8-10]$, the supply temperature of LTDH can be as low as just above $50^{\circ} \mathrm{C}$. Such temperature level has been tested by many cases sufficient to supply comfort room heating[11-13]. It is also able to heat DHW to the required temperature to suppress the growth of bacteria 
such as Legionella, without any supplementary heating. In contrast, ultra-lowtemperature district heating (ULTDH), with the supply temperature lower than the LTDH, is unable to independently generate DHW meeting the comfort or hygienic rule. Additional booster devices are required to further elevate the DHW temperature. Along with the district heating expanding and the distribution technology developing, the possibilities for ULTDH become enriched. In spite of the extra investment for the supplementary heating devices, ULTDH can be still beneficial by saving the distribution heat loss and utilizing the low-grade energy sources.

Moreover, from the exergy point of view, low supply temperature helps to improve the energy-quality match between the energy supply and energy demand in the heating system [14]. The heat demand is considered as low-quality energy demand, since the comfort indoor temperature for space heating $(\mathrm{SH})$ is around $20-22^{\circ} \mathrm{C}$ and the set point temperature for domestic hot water (DHW) is around $40-45^{\circ} \mathrm{C}[5,15]$. With the conventional district heating, the exergy destruction along the primary energy conversion and distribution process accounts for the most significant part $[14,16]$. From Gong and Werner [4], the district heating distribution chain can be more exergy efficient if low temperature is applied, and almost 3 quarters exergy lost during the heat distribution process can be saved. To improve the system overall efficiency, the lowtemperature heat sources and the low operation temperature are of great importance. Heat pump, which can generate heat at suitable temperature to the heat demand, is considered more often as the heat source for district heating. In Sweden, $28 \mathrm{DH}$ systems 
implement heat pump as heat supply. The largest capacity is as much as $50 \mathrm{MW}[17]$. $\varnothing$ stergaard and Andersen [18] conduct theoretical analyses according to the typical Danish DH system, and find the scenario of DH with central HP has better performance than individual HP scenario. The advantage can be further enhanced by adding booster HPs. Elmegaard et al. [19]compare the performances of different system configurations with supply temperature at $45^{\circ} \mathrm{C}$, and find the R134a HP system with hot water tank on the primary side reach the highest exergy efficiency. Ommen et al. [20] conduct theoretical investigation on the optimal use of booster HP in ULTDH for new buildings, and find the booster HPs can improve the system performance if the central HP is used for heat supply. Torio et al. [21] concluded that the geothermal heat pump is a low exergy energy sources. The exergy performance of ground source heat pump (GSHP) based heating system depends very much on the dead state definition. Lohani [22] makes simulation for building heat system supplied with different heat sources, and finds that GSHP has better performance in energy and exergy than fossil plant and air source heat pump. Meggers et al. [23] exploit and implement a concept of lowtemperature boost system for building energy supplied by integrating a PV-Thermal panel and a heat pump. The exergy destruction is much lowered by maximizing the renewable energy source temperature while minimizing the heat supply temperature simultaneously. Investigating the operation of a district heating system supplied by geothermal heat pumps, Jensen et al. [24] find that to connect the heat pumps in series can improve the performance, and the exergy efficiency of the heat production unit can achieve $50-60 \%$. In terms of the exergoeconomic analysis, Alkan et al. [25] demonstrate 
that the heat production costs per unit exergy of a GSHP heating system decreases along with the increase of the well head temperature and reference temperature.

ULTDH system, as the innovative form of district heating, has been analyzed recently by a few theoretical studies. However, further development or planning of the optimal application are hindered by the lack of documentations of practical ULTDH cases. In this study, we analyzed a practical ULTDH system supplying a low-heat-density area based on long-term measurements. The operation methods and the actual performance regarding the configuration that combines the central HP for heat generation with consumer-side boosters for DHW supplementary heating were presented concretely. Energy, exergy and economy analyses of the case system were conducted and compared with other two scenarios under LTDH and MTDH supply. The results of this study is of great importance for determining the optimal temperature levels of district heating when supplying to low-heat-density area. Moreover, the deviation of the theoretical and practical heat consumption from the consumer side were investigated, which is crucial for selecting the optimal local booster for ULTDH and consequently improving the overall system performance.

\section{Method}

\subsection{Description of the case ULTDH system}

The case study is located in Bjerringbro, Denmark. The principle of the full-scale project is to combine the heating and cooling together as a cascade energy system. To be more specific, a cascading use of geothermal has been established by extracting cold ground 
water $\left(6^{\circ} \mathrm{C}\right.$ or $\left.12^{\circ} \mathrm{C}\right)$ for cooling purpose of an industry consumer. Afterwards, the obtained waste heat is boosted by the central heat pump and utilized for district heating. The central heat pump is responsible for supplying heat to a low-heat-density area with 21 single-family houses. The DH supply temperature from the heat pump unit is at $47^{\circ} \mathrm{C}$ for most of the operation time. Weather compensation was considered to ensure sufficient heat supply during the extremely cold period. The DH supply temperature will be increased by $1{ }^{\circ} \mathrm{C}$ for every $1^{\circ} \mathrm{C}$ reduction on outdoor temperature as long as the outdoor temperature was lower than $5^{\circ} \mathrm{C}$. When the design outdoor temperature is reached, the maximum compensation $\left(17^{\circ} \mathrm{C}\right)$ will be added on the supply temperature, as Figure 1 shows.

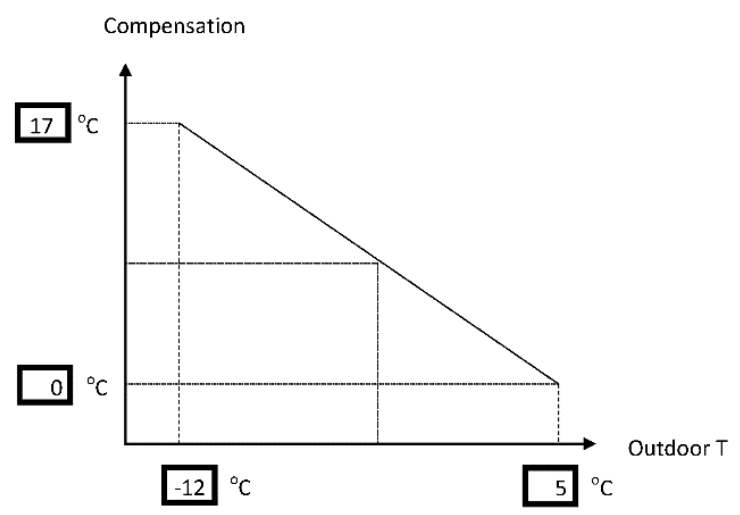

Figure 1 Regulation of ULTDH supply temperature considering the weather compensation According to Lund et al. [5], it is possible to maintain comfort room temperature with district heating supply temperature around $40^{\circ} \mathrm{C}$. The $\mathrm{DHW}$ preparation is more crucial part that limits the implementation of ULTDH. For example, from the Danish standard [15], the comfort DHW temperature for the kitchen use is $45^{\circ} \mathrm{C}$ and $40^{\circ} \mathrm{C}$ for the hand washing or showing. Concerning the hygienic risk of Legionella growth (with the 
reproduction temperature range $25-45^{\circ} \mathrm{C}$ ), for the systems with hot water storage or with large pipe networks, the DHW storage tank should be maintained no lower than $55^{\circ} \mathrm{C}$, and the system should have no point with the temperature below $50^{\circ} \mathrm{C}[26]$. While for the compact DHW system with the total volume from the heat exchanger to the tap less than 3 litres, the risk of being contaminated by Legionella is much reduced, and high temperature is not strictly required according to German Standard[27]. In this study, all houses connected to the ULTDH grid have local supplementary heating devices to boost the temperature of DHW to the required level. In addition to the central heat pump, a CHP plant with the heat output capacity of 15.5MW and a heat only-boiler with the heat output capacity of 29MW were operated mainly as the heat supplier for the MTDH network in the city. However, they were also responsible of delivering heat to the ULTDH network during the peak load period and the idling period of the heat pump. The schematics of the full-scale system is shown in Figure 2.

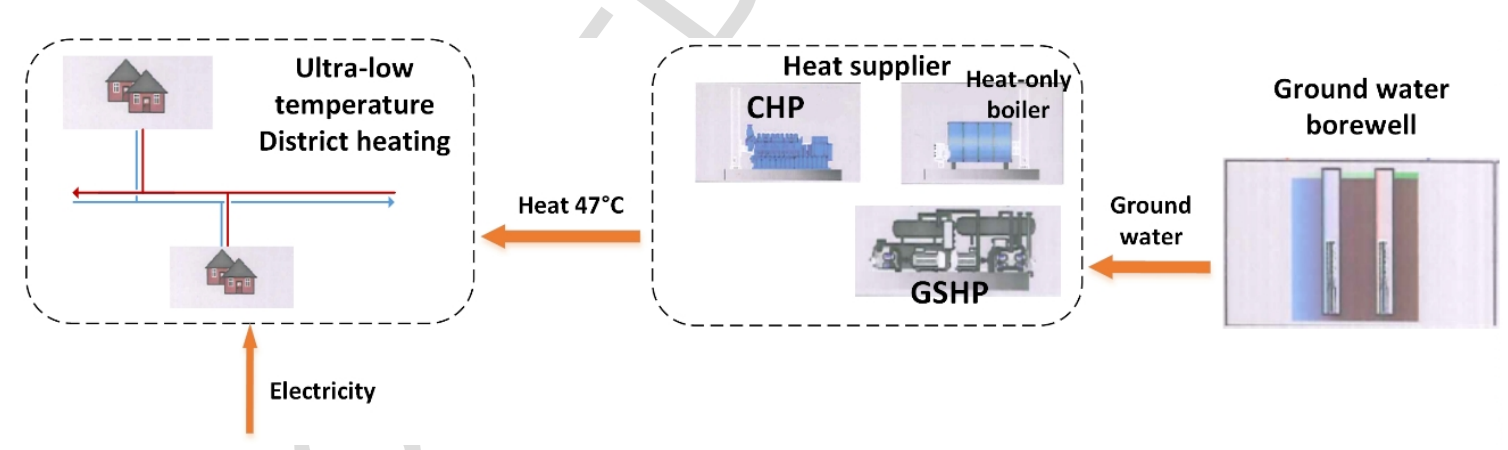

Figure 2 Schematics of the ULTDH system with geothermal heat source

The heat production from the GSHP, DH supply/return temperatures at the heat production side, heat consumption at the consumer side, supply/return temperature in every single substation in the ULTDH network, and the electricity consumption of supplementary heating were measured for long-term. 
The analysis was made on one-year measurements from May 2015 to April 2016. The following figure shows the variation of the monthly heat demand of the ULTDH network and the monthly heat output of the central heat pump based on measurements.

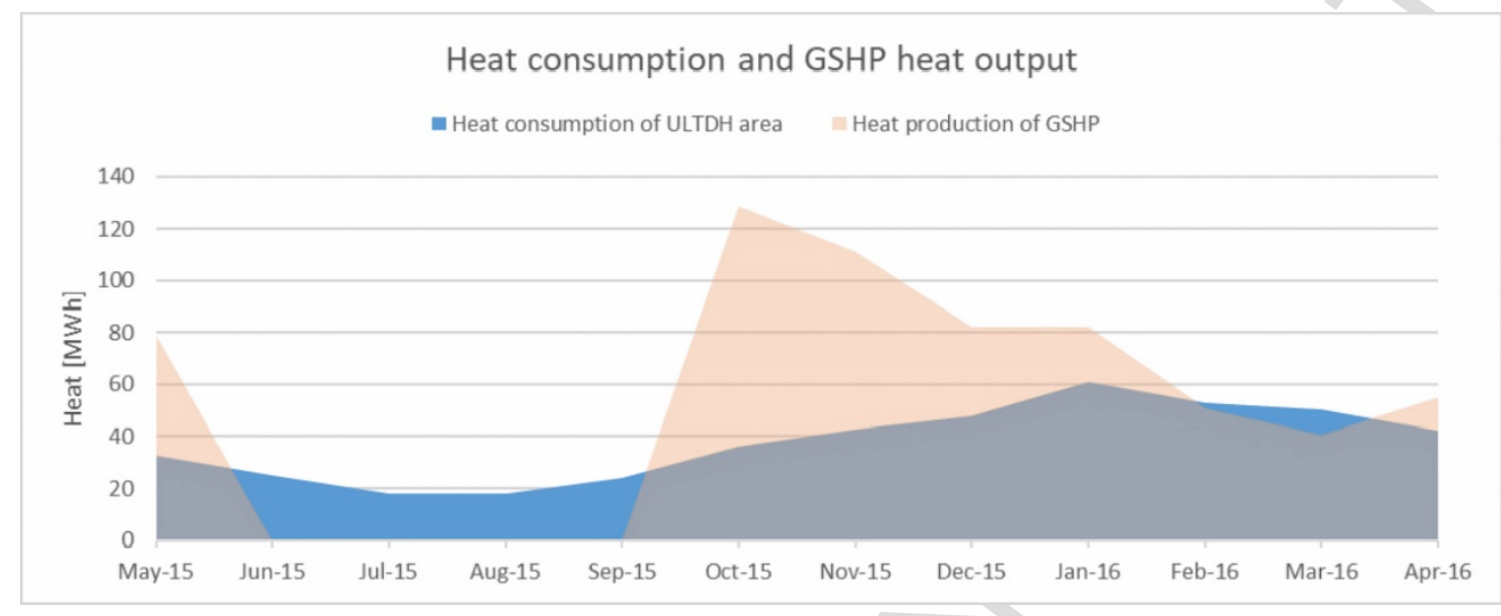

Figure 3 Measured heat consumption of the ULTDH network and heat output of the central heat pump from May 2015 to Apr 2016

To avoid evident changes on the ground temperature, the GSHP was out of operation during June to September. Most of the other period, the heat output of GSHP was larger than the heat demand. The excess heat production was used as supplementary heat supply to other area with ordinary district heating system. Due to the strategy of making utmost use of the renewable energy sources, the basic heat demand of the ULTDH network was covered by the central heat pump. During the idling period of central heat pump and the peak load period in February and March 2016, the CHP plant and heatonly boiler extracted required amount of heat from their total heat output to cover the demand from the ULTDH network. 


\subsection{Energy performance of the case ULTDH system with multiple energy sources}

For the case ULTDH network, the central heat pump alone is insufficient to cover the whole heat demand annually, thus two other heat plants as well as the local boosters were integrated for heat supply. The interaction between the central heat supplier and local energy booster increases the uncertainty of dispatching the heat generation from both sides, thereby influencing the overall energy performance of the ULTDH system. Therefore, the energy inputs from different sources were investigated in this study. Moreover, it is of interest to investigate the potential of the renewable energy being utilized as the heat source for the ULTDH and the corresponding efficiency, since one benefit of ULTDH network is the possibility of utilizing more renewable energy.

The sketch of the ULTDH system is shown in Figure 4 :

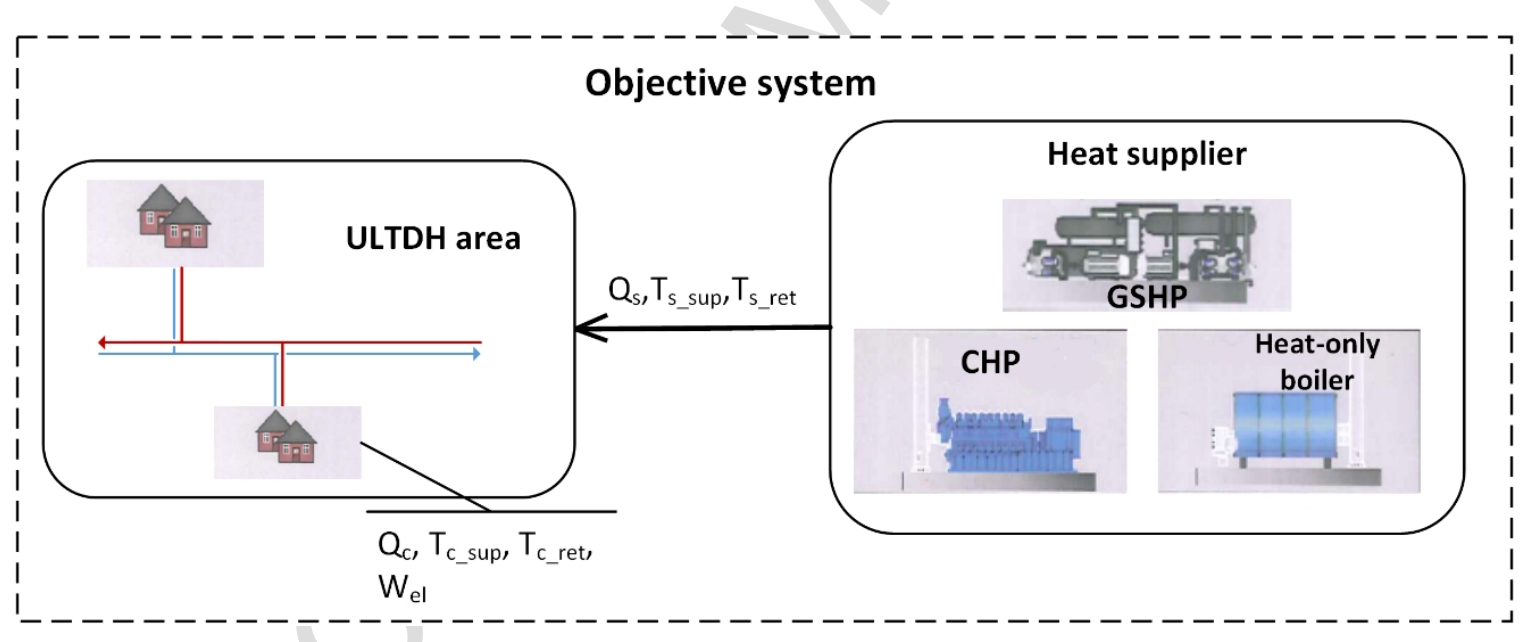

Figure 4 System boundary for energy performance analyses

As shown in the diagram, the supply and return temperatures of the ULTDH network (Ts_sup, Ts_ret) were measured. During the period when CHP or heat-only boiler is operated, though the temperature of heat generated from the CHP and the heat-only boiler is higher than the ULTDH supply temperature, mixing with lower temperature 
water flow was well controlled to make sure the final supply temperature to the ULTDH is around $47^{\circ} \mathrm{C}$. Figure 5 shows the monthly supply/return temperatures:

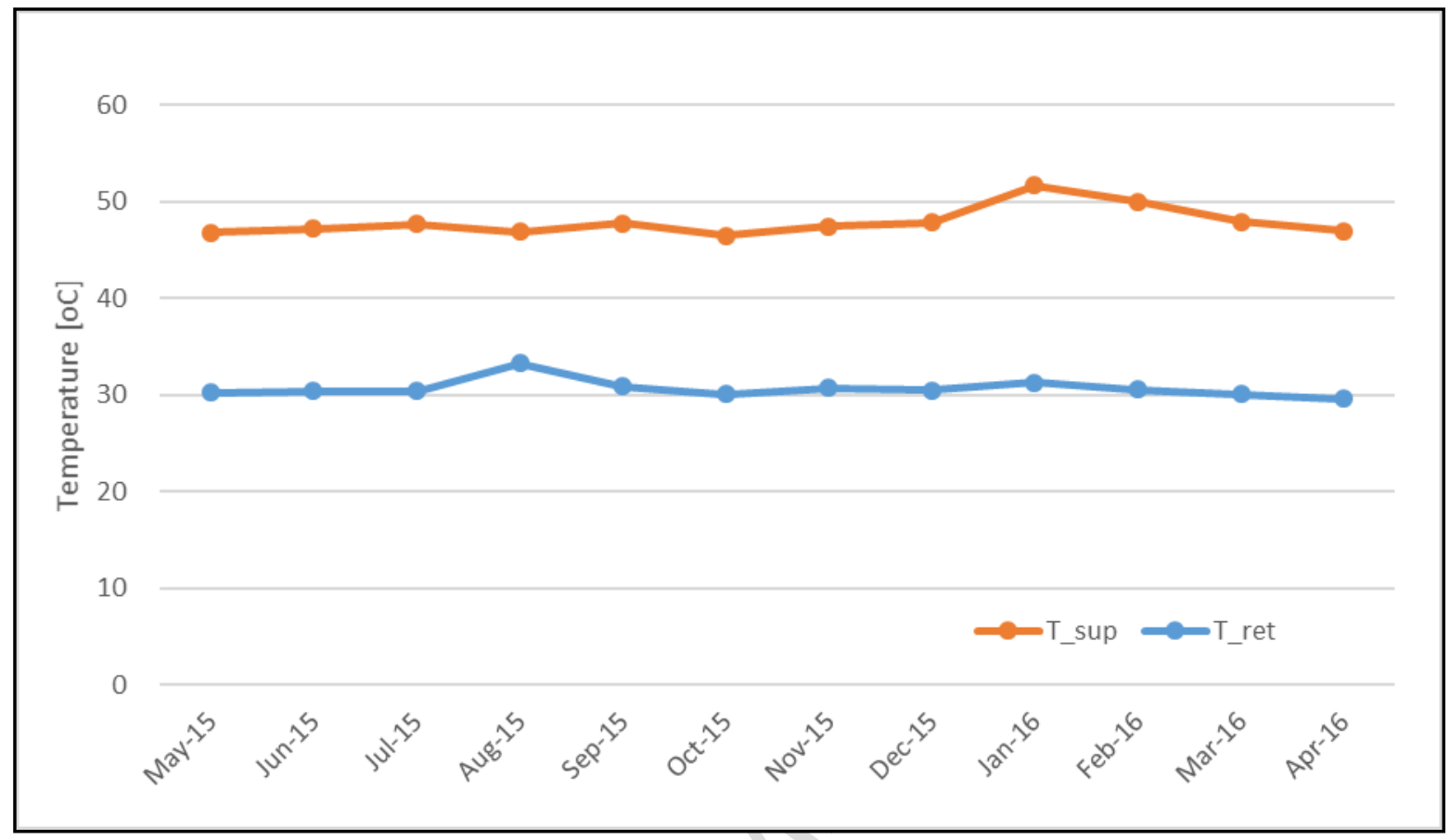

Figure 5 Measurements of monthly supply/return temperature at the heat production side during May 2015- April 2016

For most of the year, the supply temperature was around $47-48^{\circ} \mathrm{C}$, except for the coldest months- January and February 2016 when the supply temperature was $52{ }^{\circ} \mathrm{C}$ and $50^{\circ} \mathrm{C}$ respectively. However, such temperature levels are still much lower than the conventional district heating.

The total heat supplied (Qs) from the central heat supplier as well as electricity input from the local booster were both measured to investigate the energy supplied from different sources. The distribution heat loss is covered by the central heat supply (Qs). It is calculated as the subtraction between the central heat supply (Qs) and heat consumption measured at the consumer side. The distribution efficiency can be calculated accordingly. 


\subsubsection{Utilization of the Renewable energy}

The utilization of the renewable energy, which is used to replace the fossil fuels for district heating, is determined by the utilization of geothermal energy through the central heat pump and the energy input from all sources to the ULTDH network. The actual coefficient of the performance (COP) of the heat pump was measured to specify the heat and electricity consumption respectively.

The utilization coefficient is calculated as:

$$
\varepsilon_{r}=Q_{\text {geo_h }} /\left(Q_{C H P \& b o i l e r}+Q_{\text {geo_h }}+W_{\text {geo_el }}+W_{e l}\right)
$$

Where

$Q_{g e o_{-} h}$ is the geothermal heat used by the central heat pump [MWh],

$\mathrm{Q}_{\text {CHP\&boiler }}$ is the heat supplied by CHP and boiler [MWh],

$W_{\text {geo_el }}$ is the electricity that drives the central HP [MWh],

$W_{e l}$ is the electricity consumption from the local booster [MWh],

If $\varepsilon_{r}$ is higher, it means the renewable energy plays a more important role in the unit heat supply.

\subsubsection{Distribution efficiency of the ULTDH network}

In addition to the measurements at the heat supply side, measurements were also performed at the heat consumer side. Since the thermal meters were installed in the inhouse substations, they only measured the net heat consumption (incl. space heating and domestic hot water), excluding the distribution heat losses in the network. The heat 
loss inside the houses was considered as useful heat to maintain the comfort room temperature. The electricity consumption for DHW preparation from the local supplementary heating devices was also measured. The local supplementary heating for DHW preparation is utilized whenever necessary, concerning the national comfort and hygiene requirements.

Considering the interaction between central heat supplier and local booster, the heat dispatched from each side varies dynamically. Consequently, the relative heat losses of the ULTDH network compared to the central heat supply also fluctuates. Since the distribution heat loss plays an important role in the overall heat distribution efficiency of low-heat-density area, the relative heat distribution losses $\left(q_{h l}\right)$ and the distribution efficiency $\left(\varepsilon_{\text {grid }}\right)$ were investigated by the actual measurements, which the can be calculated as:

$$
\begin{aligned}
& q_{h l}=Q_{h l} / Q_{s}=\left(Q_{S}-\Sigma Q_{C}\right) / Q_{S} \\
& \varepsilon_{\text {grid }}=1-q_{h l}
\end{aligned}
$$

Where

$\Sigma Q_{c}$ represents for the summation of the heat consumption from all houses in the area [MWh],

$Q_{S}$ is the total heat supplied to the ULTDH network.

\subsection{Exergy performance of the case ULTDH network}

Exergy analysis, which combines the first and second law of thermodynamics, is used to describe the maximum useful work of an energy or mass flow in relation to its 
environment [16]. The definitions of system boundary and reference temperature are of great importance to the evaluation of exergy performance. Figure 6 shows the exergy flows into and out of the case system:

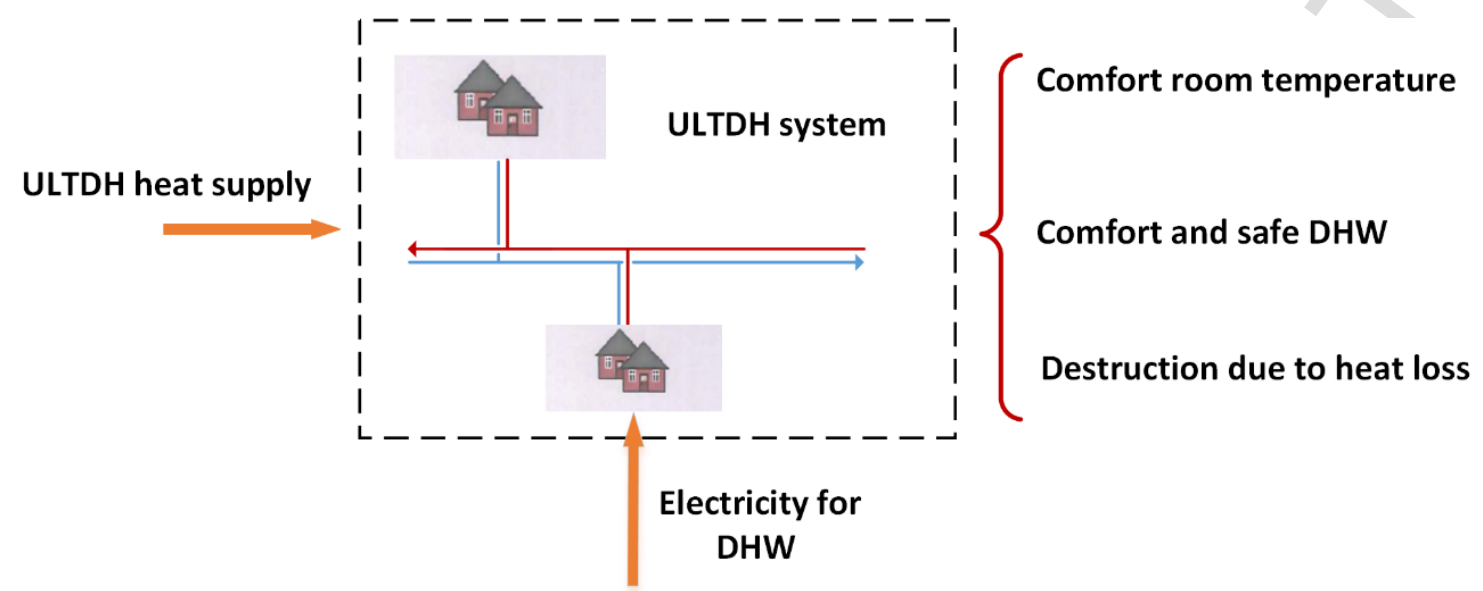

Figure 6 System boundary for exergy analysis

The exergy flows into the system come from the ULTDH central suppliers and the local boosters. The exergy flows out of the system comprise the exergy of the space heating demand and the exergy of the DHW demand. The exergy destruction is the difference between the exergy input and output, which was assumed to be the distribution heat loss in this case. For simplicity, $7^{\circ} \mathrm{C}$ as the annual average ambient temperature of Denmark was used as the reference temperature[4,28], the exergy inputs, and exergy outputs are expressed in the following equations[29]:

$$
\begin{aligned}
& \dot{E x_{D H}}=Q_{S} \cdot\left[1-\frac{T_{0}}{\left(T_{s_{s} \text { sup }}-T_{s_{-} r e t}\right)} \ln \left(\frac{T_{s_{s} \text { sup }}}{T_{s_{-} r e t}}\right)\right] \\
& E x_{D H W}=Q_{D H W} \cdot\left[1-\frac{T_{0}}{\left(T_{c_{-} D H W}-T_{\text {cold }}\right)} \ln \left(\frac{T_{c_{-} D H W}}{T_{\text {cold }}}\right)\right] \\
& \dot{E x_{S H}}=Q_{S H} \cdot\left[1-\frac{T_{0}}{T_{\text {room }}}\right]
\end{aligned}
$$




$$
\theta_{i}=\frac{E x_{i}}{Q_{i}}
$$

Where

$T_{0}$ is the reference temperature of the environment $\left[{ }^{\circ} \mathrm{C}\right]$,

$T_{S_{-} \text {sup }}$ is the supply temperature at the supply side $\left[{ }^{\circ} \mathrm{C}\right]$,

$T_{s_{-} r e t}$ is the return temperature at the supply side $\left[{ }^{\circ} \mathrm{C}\right]$,

$T_{C_{-} D H W}$ is required temperature for $\mathrm{DHW}$, which was assumed to $45\left[{ }^{\circ} \mathrm{C}\right]$,

$T_{\text {cold }}$ is the cold water temperature, which was assumed to $10\left[{ }^{\circ} \mathrm{C}\right]$,

$T_{\text {room }}$ is required indoor temperature for $\mathrm{SH}$, which was assumed to $20\left[{ }^{\circ} \mathrm{C}\right]$,

$\theta_{i} \quad$ is the individual exergy factor for $\mathrm{SH}, \mathrm{DHW}$, or $\mathrm{DH}$ respectively.

According to the previous substantial statistical studies in Nordic countries $[4,8,30]$, the annual domestic hot water demand $\left(Q_{D H W}\right)$ was assumed to be $1 / 3$ of the total heat demand $\left(Q_{c}\right)$, while the rest $2 / 3$ is for space heating. Moreover, during the summer period (from June 2015 to September 2015), it was assumed that the consumers only had DHW demand, and the heat input was all from CHP and heat only-boiler.

To evaluate the exergy performance, the exergy efficiency was calculated.

$$
\zeta=\frac{\Sigma E x_{S H}+\Sigma E x_{D H W}}{E x_{D H}+\Sigma E x_{e l}}
$$

Where,

$E x_{e l}$ is the exergy of electricity by local supplementary heating [MWh],

Since the electricity was consumed locally, the corresponding transmission losses was neglected. Thus, the exergy input from the local supplementary heating devices was 
considered as the same as their electricity consumption. The electrical supplementary heating was operated all year round to boost the DHW temperature.

\subsection{Comparisons with LTDH and MTDH network}

To figure out the optimum operation temperature level for low-heat-density area as the case study, two other scenarios using different heat sources were built artificially to compare with the case study. One is LTDH system with temperature level of $55 / 25^{\circ} \mathrm{C}$. With efficient compact heat exchanger, LTDH is sufficient to produce DHW instantaneously to meet the demand at the required temperature [31]. It was assumed that all houses in the LTDH scenario were equipped with compact heat exchanger with sufficient heat-transfer surface, so that no local electrical supplementary heating is needed. The other scenario is MTDH with supply/return temperature at $70 / 40{ }^{\circ} \mathrm{C}$. All three scenarios are supposed to supply for the same heat demand. Furthermore, the provided room temperature and DHW temperature are supposed to reach the same level concerning the requirements from the standards.

For different DH scenarios, due to the different supply temperature levels, the options for heat generator can be various considering the efficiency and economy factors. Therefore, the scenario comparisons did not include the comparison of the production side. Instead, the comparison in this study mainly focuses on the distribution network and the consumer side on fair basis.

Regarding to the distribution heat losses of the LTDH and MTDH scenarios, it can be calculated as:

$$
Q_{H L}=\Phi * L * \Delta T
$$


Where,

$\Phi$ is the heat loss coefficient of the pipe (including insulation) $[\mathrm{W} / \mathrm{m} \cdot \mathrm{K}]$,

$L$ is the length of specific pipe segments [m],

$\Delta T$ is the temperature difference between the pipe and the ground [K].

Since the comparison is made on an existing network, it was assumed pipe dimensions and insulation were kept the same for three district heating scenarios. Therefore, the distribution heat loss is proportional to the temperature difference.

\section{Results}

\subsection{Contribution of different energy sources for the ULTDH network}

The measurements of all the energy input to the ULTDH network by different sources are shown on monthly basis.

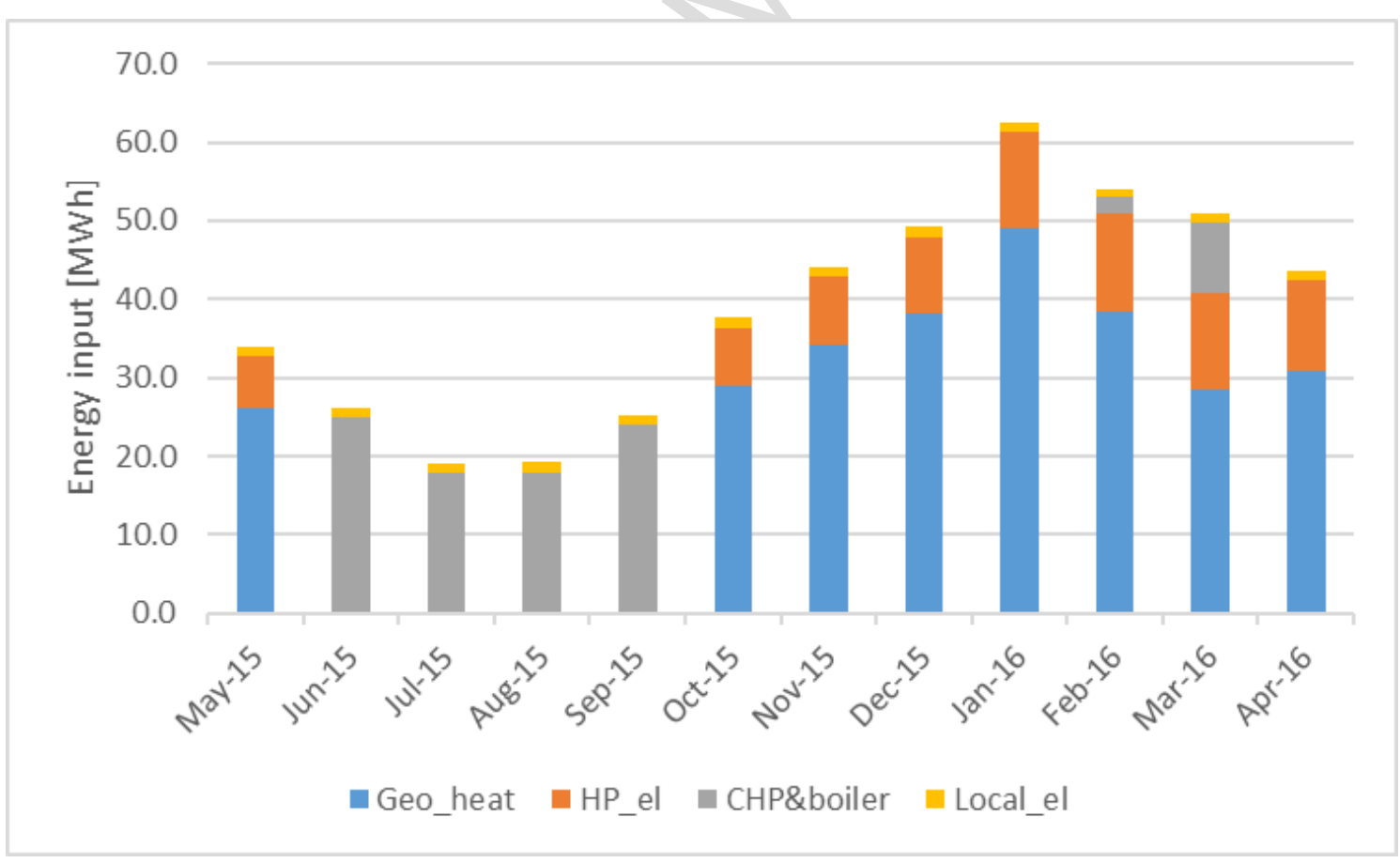

Figure 7 Contribution of energy inputs from different sources for the ULTDH network 
As shown in the diagram, during the operation period, the geothermal heat accounts for the most significant part for covering the heat demand, while small amount of electricity is required to drive the central HP. CHP and heat-only boiler were operated during the idling period of the central HP and to cover the peak load under extremely cold weather condition. The electricity consumption of the local booster appears all the year, however, the amount is tiny compared to other energy inputs.

For the operation of the central heat pump, the measured electricity consumption and COP are shown in Table 1.

Table 1 Measurements of the electricity consumption of the central HP and COP

\begin{tabular}{lllllllllllll}
\hline [MWh] & May- & Jun- & Jul- & Aug- & Sep- & Oct- & Nov- & Dec- & Jan- & Feb- & Mar- & Apr- \\
& 15 & 15 & 15 & 15 & 15 & 15 & 15 & 15 & 16 & 16 & 16 & 16 \\
\hline $\begin{array}{l}\text { Electricity of } \\
\text { central HP }\end{array}$ & 7 & - & - & - & - & 7 & 9 & 10 & 12 & 13 & 12 & 11 \\
COP & 5.04 & - & - & - & - & 5.04 & 4.98 & 4.92 & 5.03 & 4.06 & 3.35 & 3.68 \\
\hline
\end{tabular}

From the measurements, the COP ranged from 3.35 to 5.04 during the operation period of the central heat pump. The highest COP was achieved at the beginning of the heating season (Oct. 2015). Afterwards the COP decreased gradually.

By summing up the energy consumption from all sources for one year, the specific composition of the energy used for the ULTDH supply is shown in Figure 8. 


\section{Compostions of different energy sources}

Local booster El,

3\% Heat-only boiler

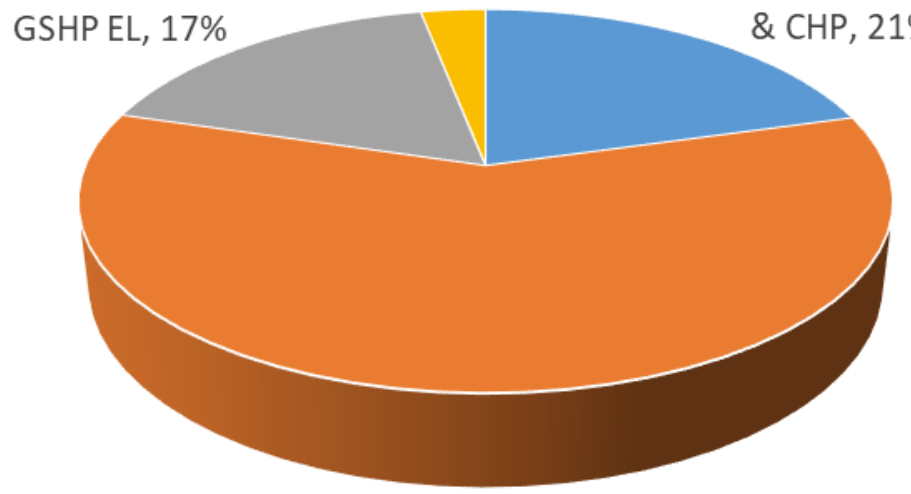

Geothermal

heat, $59 \%$

Figure 8 Composition of the heat supply from different energy sources

From the results, the annual renewable energy utilization coefficient was $59 \%$ of the total energy delivered to the ULTDH network. While the heat produced by CHP and heat-only boiler from the natural gas is only responsible for $21 \%$ of the total energy input. There is another $18 \%$ of energy supply coming from electricity to drive the central heat pump. The electricity from the local boosters only accounts for $3 \%$ of the overall energy input. There is possibility of making all the electricity consumption from renewable energy sources, which theoretically would increase the relative renewable energy consumption of the case system up to $79 \%$.

\subsection{Distribution efficiency of the ULTDH network}

The variation of the heat consumption and electricity consumption at the consumer side as well as the corresponding distribution efficiency over the year are shown in Figure 9. 


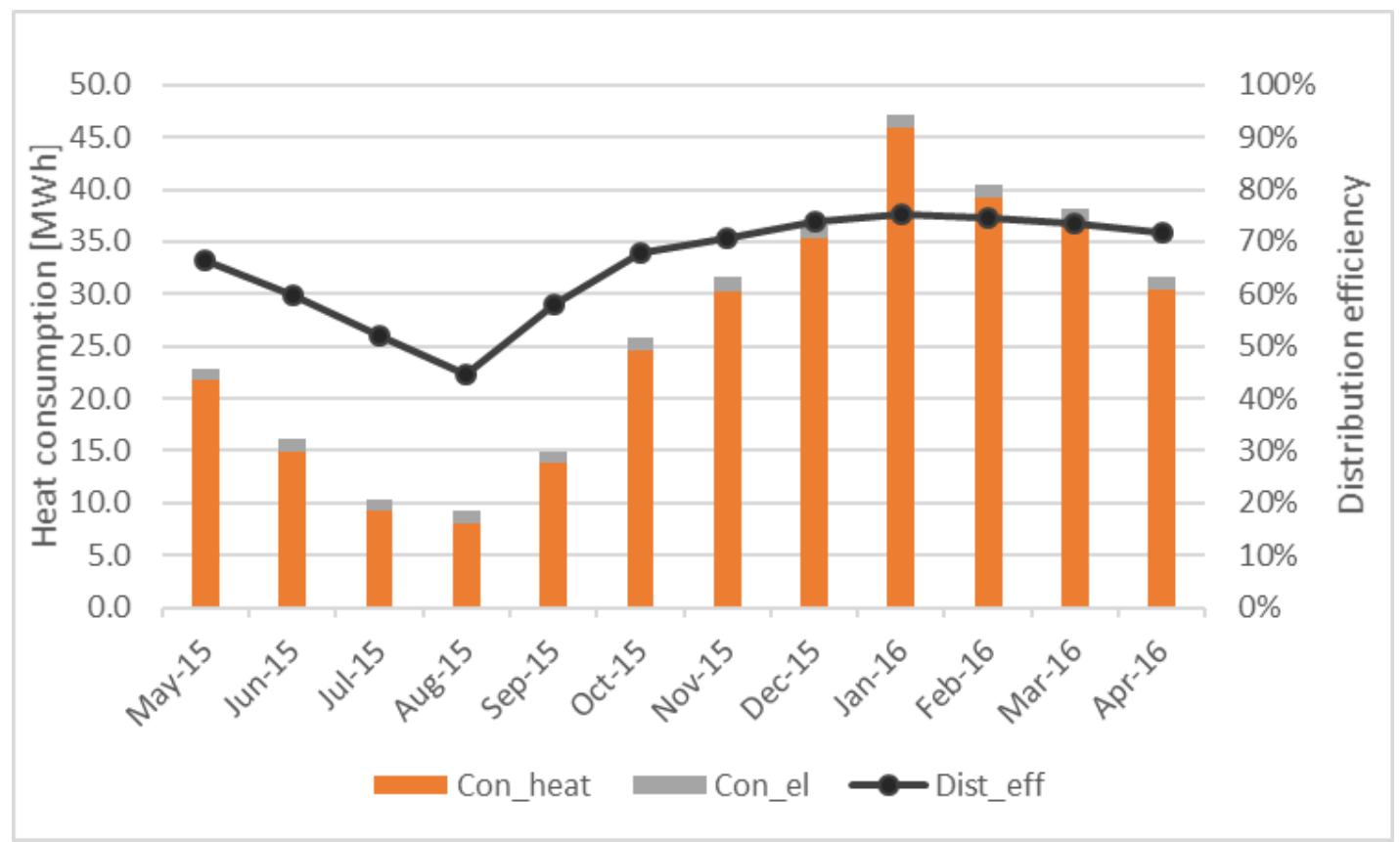

Figure 9 Proportion of heat/ electricity consumption and distribution efficiency of the ULTDH network

Figure 9 shows that the requirements of the electrical supplementary heating is limited under ULTDH, which only accounts for $4 \%$ of the local energy consumption for heating. The electricity consumption was relatively stable because it is only used for DHW preparation.

By comparing the heat consumed at all the houses and the total heat supplied to the area, the distribution efficiency of the LTDH network is also shown in the diagram. Considering the very low heat density of the area, ULTDH network has decent distribution efficiency during the winter season when the heat demand was larger. The highest distribution efficiency reached $75 \%$ in January and February. While during the summer period, the heat loss accounts for a significant proportion of the total heat supply. The lowest distribution efficiency occurred in August, which was $45 \%$. If taking an annual average, $31 \%$ of the total heat input was wasted for covering the distribution 
heat loss. The very low heat density of the ULDH network is the main reason for the large overall distribution losses.

\subsection{Exergy efficiency of the ULTDH network}

Based on the assumption in 2.3.1, the individual exergy factors for exergy consumed for space heating and DHW at the consumer side were calculated ( $5 \%$ for space heating and 7\% for DHW). From June to September, the overall exergy factor of heat consumption only considered the DHW demand. While for the other period of the year, the exergy factor is calculated to $6 \%$ concerning both space heating and DHW with their specific share in the total heat demand. Accordingly, the results of exergy inputs from $\mathrm{DH}$ and electricity, as well as the exergy efficiency of the objective ULTDH system are shown in Table 2.

Table 2 Exergy inputs to the ULTDH system and exergy efficiency on monthly basis

\begin{tabular}{lllllllllllll}
\hline [MWh] & May- & Jun- & Jul- & Aug- & Sep- & Oct- & Nov- & Dec- & Jan- & Feb- & Mar- & Apr- \\
& 15 & 15 & 15 & 15 & 15 & 15 & 15 & 15 & 16 & 16 & 16 & 16 \\
\hline $\begin{array}{l}\text { Exergy of heat } \\
\text { input }\end{array}$ & 3.3 & 2.5 & 1.8 & 1.9 & 2.5 & 3.6 & 4.4 & 4.9 & 6.7 & 5.6 & 5.2 & 4.3 \\
$\begin{array}{l}\text { Exergy of } \\
\text { electricity input }\end{array}$ & 1.1 & 1.2 & 1.0 & 1.3 & 1.1 & 1.3 & 1.3 & 1.3 & 1.2 & 1.1 & 1.2 & 1.2 \\
$\begin{array}{l}\text { Total exergy } \\
\text { input }\end{array}$ & 4.5 & 3.7 & 2.8 & 3.2 & 3.6 & 4.9 & 5.7 & 6.2 & 7.9 & 6.7 & 6.4 & 5.5 \\
$\begin{array}{l}\text { Exergy } \\
\text { efficiency [\%] }\end{array}$ & $29 \%$ & $29 \%$ & $24 \%$ & $19 \%$ & $28 \%$ & $30 \%$ & $31 \%$ & $33 \%$ & $34 \%$ & $34 \%$ & $34 \%$ & $32 \%$ \\
\hline
\end{tabular}

The results indicates the distribution efficiency plays a role in the exergy performance of the ULTDH network. The exergy efficiency reaches the maximum value during the coldest months when the relative heat loss was the lowest, while it decreases during the warmer months when the distribution efficiency was lower. 


\subsection{Actual DHW consumption and local boosters}

For ULTDH, due to the comfort and hygiene requirements to DHW temperature, the local supplementary heating devices are necessary. Electricity, as the high-quality energy input to heat the DHW further to the required temperature, is consumed by different manners according to the booster types. Consequently, the local booster plays an important role in the overall system energy and exergy efficiency. Very few studies have investigated the impacts of the local boosters. Köfinger et al. [32] compare the performance of booster HPs and direct electrical heaters in combination with ULTDH. While in this case study, more types of local boosters with different system configurations were installed in different houses according to the consumers' wish. Thermal meters were set both on DH service pipes to the substation and on the DHW circuit in 5 selected houses from July 2015 to the next March. The comparison among the performances of different local boosters can be found in the previous research [33]. Furthermore, we investigated the actual DHW consumption, as well as the proportion of the energy consumed for DHW compared to the total energy consumption. Taking the average by the test period ( 9 months), from the results shown in Figure 10, the DHW preparation only requires $5 \%-13 \%$ of the total energy consumption for heating purpose. That is much less than the recommended ratio from references, which means the electricity consumption can be much lower than the theoretical estimation. However, due to the lack of measurements in other houses in the ULTDH area, the reference value of relative energy demand for DHW was used in this study. 
From the results, in the houses with direct electrical heaters, the energy used for DHW accounts for smaller share in the total energy input, while other systems have to consume more energy to keep the big water storage warm and cover larger heat losses. In terms of the relative electricity consumption for DHW preparation, the direct electrical heater systems unnecessarily consume more electricity compared to the tank solution, while the micro heat pump system had best performance. Such information is useful to adjust the deviation between the reference- based theoretical exergy analyses and the practical performance of similar building typology. Together with the results of the relative electricity consumption, it is helpful for selection of the optimal local booster according to actual situations.

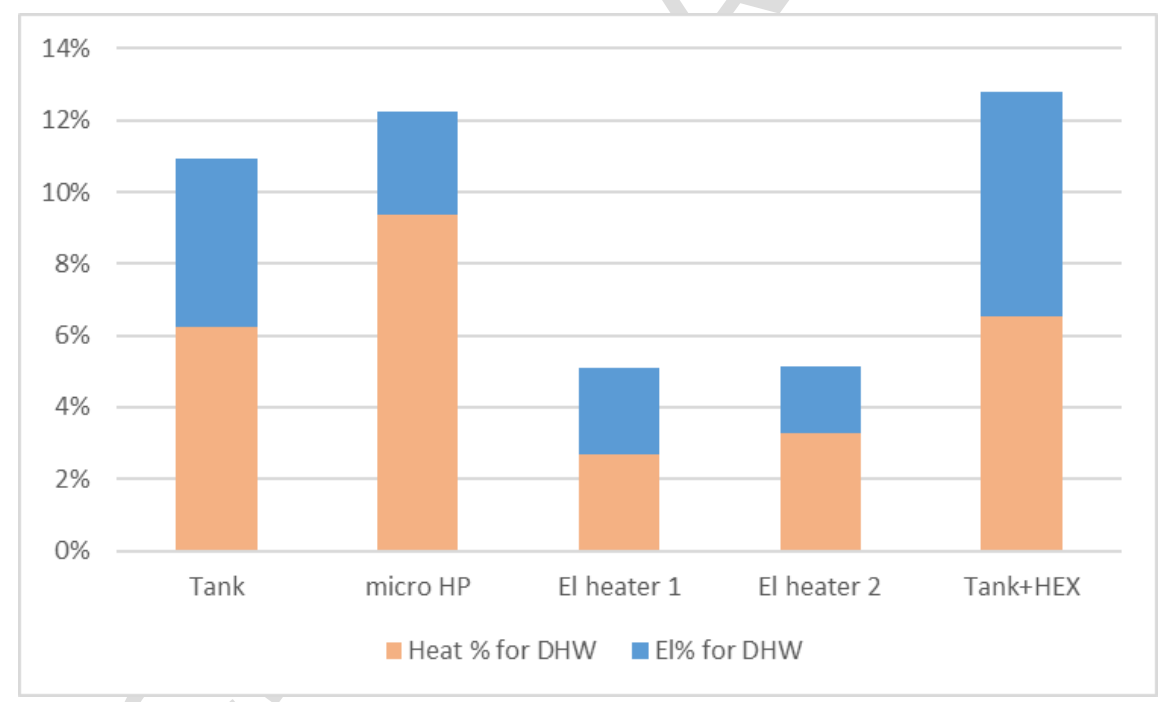

Figure 10 Relative heat and electricity consumption for DHW compared to the total energy input in the five house (averaged for the whole testing period)

3.5 Comparison of different scenarios

\subsubsection{Energy performance of three DH scenarios}

Regarding to the energy performance, Figure 11 shows the distribution efficiency of three different scenarios on monthly basis. 


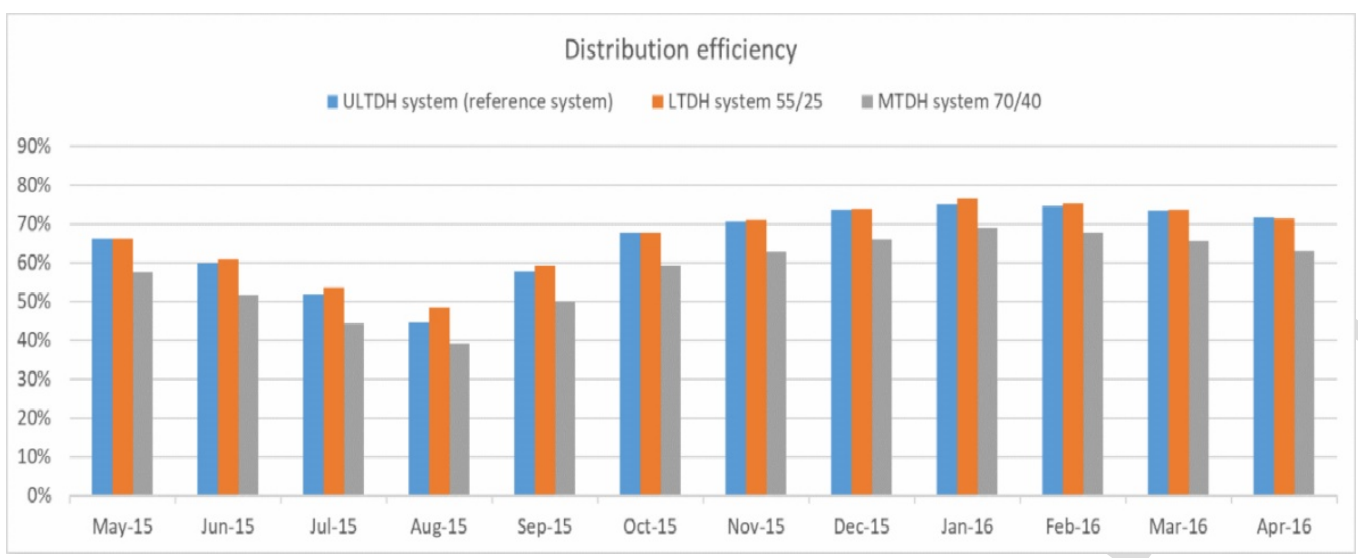

Figure 11 Distribution energy efficiency of the three scenarios

All three scenarios show the similar variation that the distribution efficiency is higher in cold season than in warm season. The distribution efficiency of the ULTDH and LTDH networks are close, which were $66 \%$ and $67 \%$ on the annual basis respectively. Both the ULTDH and LTDH networks show much higher efficiency than the MTDH network at $70 / 40{ }^{\circ} \mathrm{C}$. The average difference is $8 \%$ on a yearly basis.

\subsubsection{Exergy performance of three $\mathrm{DH}$ scenarios}

In terms of the exergy performance, the results show different feature. Figure 12 demonstrates the exergy efficiencies of the three scenarios.

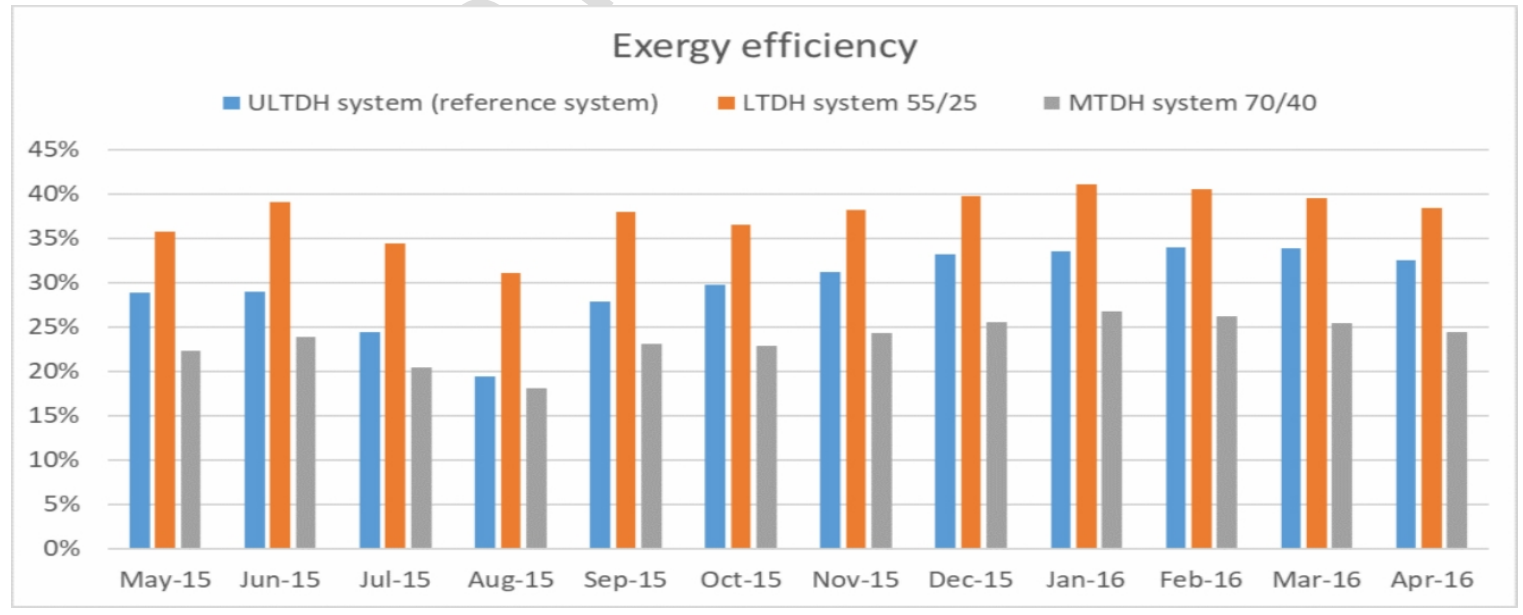

Figure 12 Exergy efficiency of the three scenarios 
The variations of all scenarios are still similar. However, the LTDH system show better exergy efficiency compared to the other two scenarios. The reason is that, the LTDH network has less exergy destruction due to the low distribution heat loss because of the low supply/return temperature levels. Moreover, the LTDH is just sufficient to provide comfort room temperature and DHW without supplementary heating by other energy sources, which means the exergy input is only from district heating. While for the ULTDH system, even the exergy destruction by the distribution heat loss is also low, the involvement of local electrical supplementary heating raised the overall exergy destruction remarkably. However, the ULTDH system still has better exergy performance compared to the conventional medium temperature system. That means, for the low-heat-density area, it is more beneficial to apply low operation temperatures combined with local temperature booster compared to increase the $\mathrm{DH}$ supply temperature centrally. Since in such cases, the distribution heat loss plays a significantly important role in the overall energy and exergy performance.

\subsubsection{Economy performance of three $\mathrm{DH}$ scenarios}

For the economy comparison, the marginal cost of heat supply were analyzed for the three scenarios. In Denmark, the cost of heat produced by CHP and heat-only boiler is around $0.8 \mathrm{DKK} / \mathrm{kWh}$, the cost of electricity is $2 \mathrm{DKK} / \mathrm{kWh}$, the marginal cost of the heat from the ground water is negligible, simplified economy analysis on yearly basis was made among the three different scenarios.

For the case ULTDH network, the heat supply from the central GSHP consists of 274 MWh geothermal energy and $81 \mathrm{MWh}$ electricity. The $\mathrm{CHP} /$ heat only-boiler provided 
$96 \mathrm{MWh}$ heat in total from the natural gas. Therefore, the integrated cost for heat supply by the ULTDH system was calculated as $0.5 \mathrm{DKK} / \mathrm{kWh}$.

For the other two scenarios, the heat was assumed to be generated only by $\mathrm{CHP} /$ heatonly boiler using natural gas, therefore the heat price applied was $0.8 \mathrm{DKK} / \mathrm{kWh}$.

To cover the same heat demand, the heat costs of the three scenarios are shown in Table 3.

Table 3 Annual energy costs for heating purpose of the three scenarios

\begin{tabular}{llll}
\hline & ULTDH with GSHP & LTDH 55/ $25{ }^{\circ} \mathrm{C}$ & MTDH $70 / 40{ }^{\circ} \mathrm{C}$ \\
\hline $\begin{array}{l}\text { Total heat supply } \\
{[\mathrm{MWh}]}\end{array}$ & 451 & 468 & 533 \\
\hline $\begin{array}{l}\text { Unit cost of heat } \\
\text { supply [DKK/kWh] }\end{array}$ & 0.5 & 0.8 & 0.8 \\
\hline $\begin{array}{l}\text { Local electricity } \\
{[\mathrm{MWh}]}\end{array}$ & 14.5 & - & - \\
\hline $\begin{array}{l}\text { Unit cost of electricity } \\
{[\mathrm{DKK} / \mathrm{kWh}]}\end{array}$ & 2 & - & - \\
\hline $\begin{array}{l}\text { Annual expense } \\
{\left[10^{3} \text { DKK] }\right.}\end{array}$ & 254 & 375 & 427 \\
\hline
\end{tabular}

Due to the implementation of renewable energy with very low marginal cost, the integrated marginal cost of heat supply of the ULTDH system was less than the other two scenarios. Moreover, the overall heat consumption of the network decreased due to less distribution heat loss. Thus, only from the point of operation cost, ULTDH scenario is more beneficial for unit heat delivery even though local electricity consumption with higher price was consumed.

The investment and payback time of the central GSHP were not included in the economic analyses in this study. The reason is that in addition to district heating, the GSHP system also provide cooling to a local cooling customer. Therefore, the total 
investment of the GSHP unit should be divided according to specific heating and cooling generation. Since this study focused on the ULTDH system, the economy performance from the cooling sector was not included, so that to make a fair comparison among the three DH scenarios. In general, by adding the cooling effect of the GSHP system, the overall economy can be improved.

\section{Discussion}

When evaluating the performance of an energy system or energy process, it is necessary to combine the first and second law of thermodynamics. For example, from the energy analysis of this study, the distribution efficiencies of the ULTDH scenario and the LTDH scenario have little difference. However, from the exergy analysis, the difference is significant. The negative effect of using high-quality energy source to supply the lowquality demand was shown clearly. Therefore, it is better to apply both energy and exergy analysis to obtain clearer view of the potential of the objective system. The energy demand can be sorted into high-quality demand and low-quality demand. A highly efficient energy system should have matched energy supply and energy demand within the scope of energy quality. The heat demand in general is low-quality demand because of the low set-point temperature. Therefore, it is more efficient to supply the heating demand with low-quality energy sources, such as geothermal heat, lowtemperature waste heat, and etc. LTDH district heating is also a low-exergy heat distribution method, which can increase the potential of the heating supply and leaves more exergy content in the high-quality energy sources for other high-valued energy process. 
From this study, it is obvious that for the low-heat density area, the distribution efficiency plays an important role in the system performance. Therefore, it is recommended to operate the $\mathrm{DH}$ network under lower temperature levels. However, to determine the minimum temperature levels requires considering influential factors as much as possible, such as the actual heat density of the area, the condition of the heat sources and local substations, the insulation of the network, the relevant investment and etc., which were not fully covered by this study. However, that is of great value to be investigated in the future research, so that to clarify the optimal proposal that meets the greatest requirement of the local area.

When operating the geothermal heat pump, the changes in the ground water temperature should be considered. As shown in Figure 3, the total output capacity of the GSHP reached the apex just after the idling period. That is when the ground water has the highest temperature. Along with the heat stored in the ground being consumed, the ground water temperature reduced, which means the inlet temperature of the source side of the heat pump reduces. As a result, the COP of the heat pump decreases. Until the end of the heating season, the COP reduced by $27 \%$, which is harmful for a stable operation of the heating system and leads to insufficient heat output to ULTDH network. As Figure 7 shows, CHP and boiler have to be integrated to cover the peak load, which decreased the economy and sustainability of the system.

\section{Conclusion}

In this study, the performance of a ULTDH network supplying low-heat-density area was analysed from energy, exergy and economy point of view. A central GSHP was utilized as 
the main heat sources for the area. The supply temperature was around $47^{\circ} \mathrm{C}$ most of the year, and local boosters was applied for DHW temperature boosting. Long -term measurements were performed to reveal the actual performances. From the results, it can be concluded that:

1) It is viable to meet the heat demand with supply temperature around $47^{\circ} \mathrm{C}$ most of the year. The electricity consumption of the local booster only accounts for $4 \%$ among all different energy sources.

2) For the low-heat-density area, the distribution losses is more significant. The heat distribution efficiency of the case ULTDH system ranges from $45 \%$ to $75 \%$ according to different months.

3) With different local boosters, the energy consumption for preparing DHW accounts for $5-13 \%$ of the total energy consumption for covering heat demand.

4) The maximum exergy efficiency of the case ULTDH system varied in a similar pattern as the distribution efficiency, which reached the peak to $34 \%$ in the coldest month.

5) Both the ULTDH system and LTDH $\left(55 / 25^{\circ} \mathrm{C}\right)$ system show better distribution efficiency compared to the MTDH $\left(70 / 40^{\circ} \mathrm{C}\right.$ system). While according to the exergy analyses, the LTDH system shows higher exergy efficiency than the other two scenarios.

6) The ULTDH network shows good economy due to the cheap marginal cost of heat generated from renewable energy sources. In addition, the lower distribution losses helps to reduce the overall heat load. 


\section{Acknowledgement}

The research presented in this paper was financed by the Danish Energy Agency under the Energy Technology Development and Demonstration Programme (EUDP) (640140540) in the project entitled: "EBC - Annex 64: LavEx Samfund". The project is carried out as part of EBC Annex 64 LowEx Communities - Optimised Performance of Energy Supply Systems with Exergy Principles. The authors would like also to thank for the great support from Bjerringbro DH company in Denmark for this research.

\section{References}

[1] European Commission. 2050 Energy Strategy 2011. https://ec.europa.eu/energy/en/topics/energy-strategy-and-energy-union/2050energy-strategy (accessed May 7, 2017).

[2] Danish Ministry of Climate. Vores Energi. Copenhagen: 2010.

[3] Danish Energy Agency. Green energy - the road to a Danish energy system without fossil fuels. Copenhagen: 2010.

[4] Gong M, Werner S. Exergy analysis of network temperature levels in Swedish and Danish district heating systems. Renew Energy 2015;84:106-13. doi:http://dx.doi.org/10.1016/j.renene.2015.06.001.

[5] Lund H, Werner S, Wiltshire R, Svendsen S, Thorsen JE, Hvelplund F, et al. 4th Generation District Heating (4GDH). Integrating smart thermal grids into future sustainable energy systems. Energy 2014;68:1-11.

doi:10.1016/j.energy.2014.02.089. 
[6] Centralkomunernes Transmissionsselskab. Technical key figures [Tekniske nøgletal] [in danish] 2013. http://www.ctr.dk/teknik.aspx (accessed April 11, 2018).

[7] Dansk Fjernvarme. Benchmarking, statistics 2017 [Benchmarking, statistik 2017] [in danish] 2017. http://www.danskfjernvarme.dk/viden-om/statistiksubsection/aarsstatistik? (accessed April 11, 2018).

[8] Frederiksen S, Werner S. District heating and cooling. Lund Sweden: Studentlitteratur AB; 2013.

[9] Kaarup Olsen P. Guidelines for Low-Temperature District Heating. EUDP 2010-II Full-Scale Demonstr Low-Temperature Dist Heat Exist Build 2014:1-43.

[10] Li H, Svendsen S, Werner S, Persson U, Ruehling K, Felsmann C, et al. Annex X Final report Toward 4 th Generation District Heating : Experience and Potential of Low-Temperature District Heating Short title : Toward 4 th Generation District Heating 2014.

[11] Brand M, Svendsen S. Renewable-based low-temperature district heating for existing buildings in various stages of refurbishment. Energy 2013;62:311-9. doi:10.1016/j.energy.2013.09.027.

[12] Harrestrup M, Svendsen S. Changes in heat load profile of typical Danish multistorey buildings when energy-renovated and supplied with low-temperature district heating. Int J Sustain Energy 2015;34:232-47. doi:10.1080/14786451.2013.848863.

[13] Østergaard DS, Svendsen S. Theoretical overview of heating power and necessary 
heating supply temperatures in typical Danish single-family houses from the 1900s. Energy Build 2016;126:375-83. doi:10.1016/j.enbuild.2016.05.034.

[14] Hepbasli A. Low exergy (LowEx) heating and cooling systems for sustainable buildings and societies. Renew Sustain Energy Rev 2012;16:73-104. doi:10.1016/j.rser.2011.07.138.

[15] DS 439:2009. Norm for vandinstallationer [Code of Practice for domestic water supply] (in Danish) 2009:75.

[16] Schmidt D. Design of Low Exergy Buildings- Method and a Pre-Design Tool. Int J Low Energy Sustain Build 2003;3.

[17] Averfalk H, Ingvarsson P, Persson U, Gong M, Werner S. Large heat pumps in Swedish district heating systems. Renew Sustain Energy Rev 2017;79:1275-84. doi:10.1016/j.rser.2017.05.135.

[18] Østergaard PA, Andersen AN. Booster heat pumps and central heat pumps in district heating. Appl Energy 2016;184:1374-88.

doi:10.1016/j.apenergy.2016.02.144.

[19] Elmegaard B, Ommen TS, Markussen M, Iversen J. Integration of space heating and hot water supply in low temperature district heating. Energy Build 2015;124:255-64. doi:10.1016/j.enbuild.2015.09.003.

[20] Ommen T, Thorsen JE, Markussen WB, Elmegaard B. Performance of ultra low temperature district heating systems with utility plant and booster heat pumps. Energy 2017;137:544-55. doi:10.1016/j.energy.2017.05.165.

[21] Torío H, Angelotti A, Schmidt D. Exergy analysis of renewable energy-based 
climatisation systems for buildings: A critical view. Energy Build 2009;41:248-71. doi:https://doi.org/10.1016/j.enbuild.2008.10.006.

[22] Lohani SP. Energy and exergy analysis of fossil plant and heat pump building heating system at two different dead-state temperatures. Energy 2010;35:332331. doi:10.1016/j.energy.2010.04.018.

[23] Meggers F, Ritter V, Goffin P, Baetschmann M, Leibundgut H. Low exergy building systems implementation. Energy 2012;41:48-55. doi:10.1016/j.energy.2011.07.031.

[24] Jensen JK, Ommen T, Markussen WB, Elmegaard B. Design of serially connected district heating heat pumps utilising a geothermal heat source. Energy 2017. doi:10.1016/j.energy.2017.03.164.

[25] Alkan MA, Keçebaş A, Yamankaradeniz N. Exergoeconomic analysis of a district heating system for geothermal energy using specific exergy cost method. Energy 2013;60:426-34. doi:10.1016/j.energy.2013.08.017.

[26] European Committee for Standardization. Recommendations for prevention of Legionella growth in installations inside buildings conveying water for human consumption, CEN/TR 16355:2012 2012.

[27] DVGW W551. Drinking water heating and drinking water piping systems; technical measures to reduce Legionella growth; design, construction, operation and rehabilitation of drinking water installations. 2004.

[28] Li H, Svendsen S. Energy and exergy analysis of low temperature district heating network. Energy 2012;45:237-46. doi:10.1016/j.energy.2012.03.056. 
[29] Torío H, Schmidt D. Development of system concepts for improving the performance of a waste heat district heating network with exergy analysis. Energy Build 2010;42:1601-9. doi:https://doi.org/10.1016/j.enbuild.2010.04.002.

[30] Bøhm B, Schrøder F, Bergsøe NC. Varmt Brugsvand. 2009.

[31] Yang X, Li H, Svendsen S. Energy, economy and exergy evaluations of the solutions for supplying domestic hot water from low-temperature district heating in Denmark. Energy Convers Manag 2016;122:142-52. doi:10.1016/j.enconman.2016.05.057.

[32] Köfinger M, Basciotti D, Schmidt RR, Meissner E, Doczekal C, Giovannini A. Low temperature district heating in Austria: Energetic, ecologic and economic comparison of four case studies. Energy 2016;110:95-104. doi:10.1016/j.energy.2015.12.103.

[33] Yang X, Li H, Svendsen S. Evaluations of different domestic hot water preparing methods with ultra-low-temperature district heating. Energy 2016;109:248-59. doi:10.1016/j.energy.2016.04.109. 